\title{
Development of Chitosan/Poly(L-Lactide)/Multiwalled Carbon Nanotubes Scaffolds for Bone Tissue Engineering
}

\author{
A. De la Paz Orozco1, F. Jiménez Vega1, S. A. Martel-Estrada², A. Hernández Aguilar3, \\ M. E. Mendoza-Duarte ${ }^{4}$, M. C. Chavarría-Gaytán ${ }^{3}$, C. A. Rodríguez-González ${ }^{3}$, \\ I. Olivas-Armendáriz ${ }^{3 *}$ \\ ${ }^{1}$ Instituto de Ciencias Biomédicas, Universidad Autónoma de Ciudad Juárez, Chihuahua, México \\ ${ }^{2}$ Instituto de Arquitectura Diseño y Arte, Universidad Autónoma de Ciudad Juárez, Chih, México \\ ${ }^{3}$ Instituto de Ingeniería y Tecnología, Universidad Autónoma de Cd. Juárez, Chihuahua, México \\ ${ }^{4}$ Centro de Investigación en Materiales Avanzados, Chihuahua, México \\ Email: *iolivas@uacj.mx
}

Received 9 February 2016; accepted 14 March 2016; published 17 March 2016

Copyright (C) 2016 by authors and Scientific Research Publishing Inc.

This work is licensed under the Creative Commons Attribution International License (CC BY).

http://creativecommons.org/licenses/by/4.0/

(c) (i) Open Access

\section{Abstract}

This work focuses to improve the mechanical properties and investigates the growth of osteoblasts on a degradable chitosan/poly(L-lactide)/carbon nanotubes composite for tissue engineering. The morphological and mechanical properties characterizations were performed using scanning electronic microscopy (SEM) and rheometrics analysis system (RSA). Osteoblasts differentiation was determined by alkaline phosphatase activity, total number cells by an Alamar Blue assay, cell attachment and proliferation were visualized qualitatively using SEM, mineralization was characterized by transformed infrared spectroscopy, energy dispersive spectroscopy, and X-ray diffraction. The results suggest that the chitosan/poly(L-lactide)/multiwalled carbon nanotubes composites exhibit the ability to promote cell adhesion, proliferation, and differentiation on their surface.

\section{Keywords}

Chitosan, Poly(L-Lactide), Multiwalled Carbon Nanotubes, Mechanical Properties, Biocompatibility

\footnotetext{
"Corresponding author.
}

How to cite this paper: De la Paz Orozco, A., et al. (2016) Development of Chitosan/Poly(L-Lactide)/Multiwalled Carbon Nanotubes Scaffolds for Bone Tissue Engineering. Open Journal of Regenerative Medicine, 5, 14-23. 


\section{Introduction}

Bone structural damage is the major cause of chronic pain, disability, and loss of function, resulting in a high cost in health; subjects with bone loss, whose regeneration is poor, requiring a graft to complete the repair, and restore normal function of the bone [1]. In some cases, placing a graft is not feasible, so it is necessary to search for new options. Tissue engineering presents the use of biomaterials like biological substitutes to regenerate, maintain or improve tissue function lost, requiring artificial scaffolding, degradable, capable of initiating osteoinduction, with resorption rate that equals bone regeneration, so that the material is degraded when the lesion is completely regenerated [2].

Actually porous matrices manufactured by various techniques, have allowed the processing of natural polymer such as chitosan (Ch), or synthetic including polyhydroxy acids, such as poly(L-lactide) (PLLA) [3]. Chitosan and PLLA are biocompatible, biodegradable and bioabsorbable materials [4]-[7] which serve as a structure for the undifferentiated cells and osteogenic potential as growth factors, inducing the differentiation of osteoblasts [8]. Chitosan has a hydrophilic surface which makes it biocompatible [9]-[11]. However, it is mechanically weak, unstable and it is unable to maintain a predefined shape. As a result of swelling, it has little flexibility to adjust its mechanical properties; while the additional methyl group in PLLA makes it more hydrophobic, reducing its molecular affinity to water, leading to a slower hydrolysis [12]. Meanwhile carbon nanotubes (CNT) are among the strongest and harder materials, they have excellent mechanical, electrical [13] [14], optical, thermal and chemical properties [15], making them an excellent choice as filler in biomaterials to improve their properties [16]; since they can be customized to mimic the extracellular matrix in terms of structure, chemical composition and mechanical properties, as well as support cell growth and differentiation of osteoblasts [17]. In tissue engineering, a material with a single component cannot help mimic all the properties of bone, therefore, the development of composite materials is imperative as an alternative to bone repair.

In this work, we combined chitosan, PLLA, and Multiwalled carbon nanotubes (MWCNT) for preparing composites with good mechanical and physicochemical properties for tissue engineering applications. The objective was to evaluate the in vitro response of rat calvaria osteoblasts growth, by means of culturing them on scaffolds made of Ch/PLLA reinforced with different amount of MWCNT (0\%, 1\%, 2\%, 5\% and 10\% w/w), at 3, 7 and 14 days of cell culture. Morphology and cell viability of the composites were evaluated by scanning electron microscopy (SEM) and Alamar Blue assay respectively, osteoblast phenotype was analyzed by the activity of alkaline phosphatase (ALP); the formation of hydroxyapatite (HAp) by Fourier transform infrared spectroscopy (FT-IR) and X-ray diffraction (XRD).

\section{Materials and Methods}

\subsection{Preparation of Composites}

The MWCNT (CIMAV, Mexico) was added to the solution of $2 \%$ acetic acid and dispersed by sonication. Chitosan (Sigma-Aldrich, St. Louis, MO) and PLLA (DURECT Corporation, Cupertino CA.) were dissolved in acetic acid solution with MWCNT and chloroform. Afterwards, PLLA solution was added slowly to the chitosan solution and the mixture was stirred until a homogeneous mixture was obtained. Then, the mixture was frozen at $-78^{\circ} \mathrm{C}$ and later the solvent was extracted by a freeze-drying system for $48 \mathrm{~h}$. The composites were neutralized in an aqueous solution of $\mathrm{NaOH}-\mathrm{CH}_{3} \mathrm{CH}_{2} \mathrm{OH}(0.5 \mathrm{wt} \% \mathrm{NaOH}$ was dissolved in $80 \%$ ethanol aqueous solution) at $-20^{\circ} \mathrm{C}$ for $12 \mathrm{~h}$. Then it was immersed in pure ethanol for $12 \mathrm{~h}$ at $-20^{\circ} \mathrm{C}$. After that, it was washed with distilled water and dried in a freeze dryer respectively obtaining composites with percentages of 49.5/49.5/1, 49/49/2, 47.5/47.5/5, and 45/45/10 of chitosan, PLLA, and MWCNT.

\subsection{Mechanical Properties}

RSA III (Rheometrics Analyzes System) TA was used in static mode at a frequency of $6.2832 \mathrm{rad} / \mathrm{s}$ and at $37^{\circ} \mathrm{C}$ for all samples. Disks of approximately $10 \mathrm{~mm}$ in thickness and $25 \mathrm{~mm}$ in diameter were used in all the experiments.

\subsection{Cell Culture}

Osteoblasts calvaria cells were obtained from 14 day old Sprague Dawley rats. Osteoblastic cells were counted using an automated cell counter (Countess ${ }^{\circledR}$ automated cell counter, Invitrogen), seeding $5 \times 10^{4}$ cells into composite fragments of $10 \mathrm{~mm}$ in diameter and $3 \mathrm{~mm}$ in thick, embedded in $\alpha$-MEM medium (Sigma-Aldrich, St. Louis, MO), (supplemented with 10\% of fetal bovine serum, 3\% of gentamicin-penicillin, 3 mM of $\beta$-gly-cerol- 
phosfate and $10 \mathrm{mg} / \mathrm{mL}$ of ascorbic acid). The culture medium was renewed every two days. The cultures were maintained in an incubator at $37^{\circ} \mathrm{C}$ with $5 \%$ of $\mathrm{CO}_{2}$ and $95 \%$ of relative humidity. The composite prior to seeding were washed with distilled water to remove residual solvents, lyophilized to $-80^{\circ} \mathrm{C}$ (Labconco Free-zone) and sterilized by UV for 2 hours, remaining composites were immersed in solution $\alpha$-MEM at $37^{\circ} \mathrm{C}$ in incubator (Shel Lab model 1012) the night before planting osteoblasts.

\subsection{Cell Proliferation}

To quantify cell proliferation of the composites, a spectrophotometric method was realized using Alamar Blue ${ }^{\circledR}$ reagent following the manufacturer's instructions (Biosource, Invitrogen), mixing $100 \mu \mathrm{L}$ of Alamar Blue indicator with $900 \mu \mathrm{L}$ of $\alpha$-MEM containing 10\% FBS. For reading proliferation the biomaterial was removed from culture medium and washed by stirring in PBS $1 \times$. All samples were immediately immersed in the mixture solution of $\alpha$-MEM, FBS and Alamar Blue, leaving them to incubate for 4 hours at $37^{\circ} \mathrm{C}$. Spectrophotometric reading was measured at $570 \mathrm{~nm}$ (Benchmark Plus, BioRad microplate spectrophotometer). It was used as a calibration curve generated previously with a number of cells known.

\subsection{Alkaline Phosphatase Activity}

Alkaline Phosphatase Activity (ALP) of the osteoblasts was measured as an early marker of maintaining their phenotype, using a kit ALP substrate (Pierce Biotechnology). This colorimetric test used as a substrate p-nitrophenyl phosphate (P-NNP) and is based on the P-NNP conversion to p-nitrophenol (p-NP) in the presence of ALP. $10 \mathrm{mg}$ of PNPP were dissolved in $10 \mathrm{ml}$ of diethanolamine buffer, cells were lysed with Triton X-100 1\% DEPC-treated water and with three cycles of thermal shock. $100 \mathrm{~mL}$ were taken from the sample and $100 \mu \mathrm{L}$ of PNPP solution was added and incubated at $37^{\circ} \mathrm{C}$ for 30 minutes. Once the incubation period stopped the reaction, $50 \mu \mathrm{L}$ of $2 \mathrm{~N} \mathrm{NaOH}$ solution was added to each sample. The production of P-NP was determined by the absorbance at $405 \mathrm{~nm}$ by spectrophotometry (Benchmark Plus Microplate spectrophotometer). Plus Microplate spectrophotometer.

\subsection{SEM Analysis}

Scaffolds with osteoblasts cultured at 3, 7 and 14 days were removed from the culture medium, rinsed with PBS, placed in a new plate and immersed in a solution of $3 \%$ glutaraldehyde for 3 hours to fix the cells. The samples were dehydrated through a series of ethanol solutions (70\%, 85\%, 90\%, 95\% and 100\%) with an interval of 10 minutes between each set. The dry samples were mounted on aluminum stubs and characterize the morphology and cell proliferation in a field scanning electron microscopy (Jeol JSM7000F).

\subsection{Mineralization}

FT-IR analysis was performed using a transmission mode in an IR spectrometer (Nicolet 6700, Thermo Scientific, USA), which has a $2 \mathrm{~mm}$ diameter diamond window. All spectra were recorded between 4000 and 650 $\mathrm{cm}^{-1}$, for each spectrum 100 scans were performed at $16 \mathrm{~cm}^{-1}$. The X-ray diffraction patterns of the samples were analyzed between $2^{\circ}=5^{\circ}$ and $2^{\circ}=80^{\circ}$ with a step size of $2^{\circ}=0.02^{\circ}$ in an X-ray diffraction instrument in continuous mode (PANanalytical X'Pert PRO). All spectra were recorded using 100 scans and $16 \mathrm{~cm}^{-1}$ resolutions.

\subsection{Statistical Analysis}

All assays were performed in triplicate and the data analyzed in the statistical package Minitab 16 for Windows XP. The data obtained were evaluated for statistical significance using the Student's t-test. The results of the analyzed variables were expressed as mean \pm standard deviation and the statistical differences between the study groups and the control were considered significant when $p<0.05$.

\section{Results and Discussion}

\subsection{Microstructural and Mechanical Properties}

Figure 1 shows the images of chitosan/PLLA, chitosan/PLLA-2\%MWCNT, and chitosan/PLLA-5\%MWCNT. 


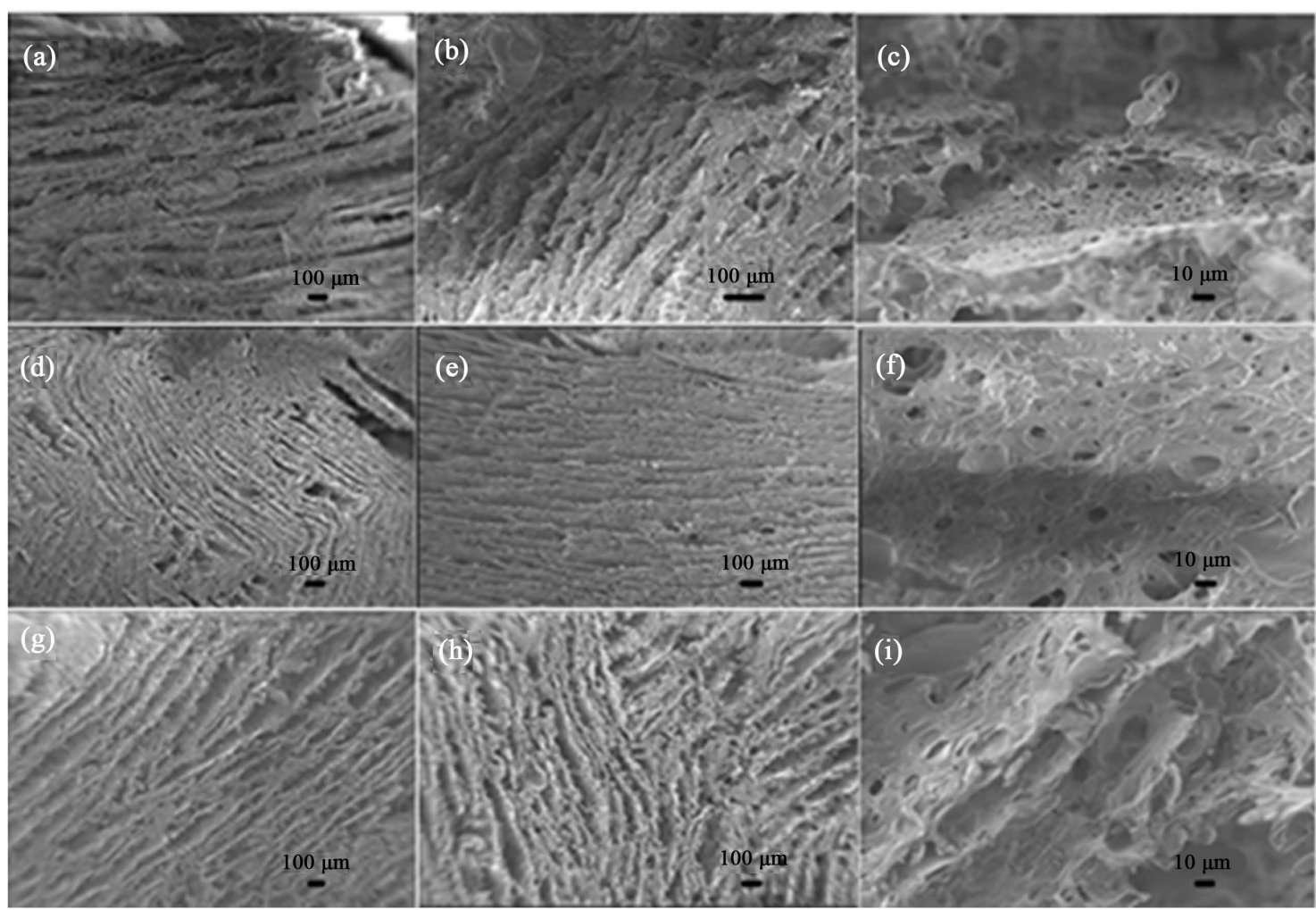

Figure 1. SEM images of chitosan/PLLA ((a), (b), and (c)), chitosan/PLLA-2\%MWCNT ((d), (e), and (f)), and chitosan/ PLLA-5\%MWCNT ((g), (h), and (i)) composites.

A similar morphology of the composites matrix with and without multiwall carbon nanotubes can be observed. Figure 1(a), Figure 1(d), and Figure 1(g) show organized morphology in sheets and/or elongated plates through the entire matrix. At higher magnifications, it is possible to observe a highly interconnected porous structure $(<30 \mu \mathrm{m})$. The morphology on the scaffolds was dominated by heat transfer and the porosity shows dependency on the route in which the phase separation between the solvents and polymers takes place, as was demonstrated in a previous work [5]. Then in Figure 1(a), Figure 1(d), and Figure 1(g) sheets forming various elongated layers in the gradient direction can be observed. The interconnected porosity could be reached inside the layers, as it is showed clearly in Figure 1(c). Furthermore, Table 1 shows a varied pore size, the average pore size of chitosan/PLLA, chitosan/PLLA-1\% MWCNT, chitosan/PLLA-2\%MWCNT, chitosan/PLLA-5\% MWCNT, and chitosan/PLLA-10\%MWCNT composite varied from $96.48 \mu \mathrm{m}$ to $51.58 \mu \mathrm{m}$ as measured by SEM. The increase in the concentration of MWCNT in the polymeric matrix, resulted in the decrease of average pore size, this trend can be attributed to carbon nanotubes that filled the space available in the pores and thus decreased the porosity of materials [17]. The pores generated in each composite have a range size from $40 \mu \mathrm{m}$ to $100 \mu \mathrm{m}$ and $100 \mu \mathrm{m}$ to $350 \mu \mathrm{m}$ (mostly), This highly porous and interconnected structure facilitates uniform distribution of the cells, optimizes biological environment, and provides an adequate nutrient flow [5] [17] [18].

The mechanical properties of composites were evaluated by means of dynamical-mechanical analysis and the results are shown in Figure 2. The incorporation of MWCNT increases the module of Ch/PLLA-1\%MWCNT composite in comparison to the Ch/PLLA composite by $26.48 \%$. Similar trends were observed between Ch/ PLLA-1\%MWCNT and Ch/PLLA-2\%MWCNT composites, showing an increase of 31.20\%. The greatest increase between a module and another was between the composites Ch/PLLA-2\%MWCNT and Ch/PLLA-5\% MWCNT (43.39\%). However, the Young's modulus of the composite containing 5\% of MWCNT and the composite containing $10 \%$ of MWCNT was similar, being the increment between modules of $9.15 \%$. This result can be due to the agglomeration of MWCNT in the composite [20], so this result confirms that lower amounts of MWCNT in the composites can significantly improve the mechanical properties [21] and offers a topography that mimics the natural tissue nanostructure, such that, add MWCNT in polymeric biomaterials induce a porous surface, favorable for cell adhesion and proliferation [22]. 


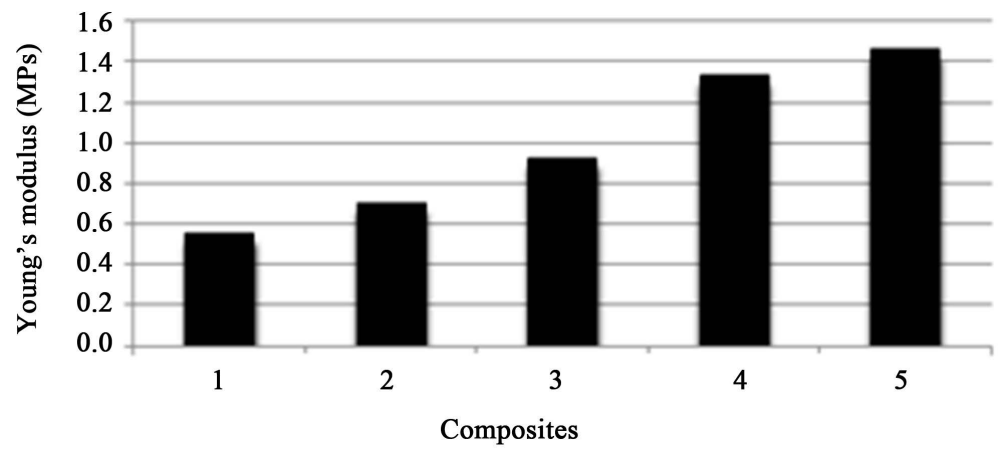

Figure 2. Variation of the Young's modulus of (1) Ch/PLLA, (2) Ch/PLLA-1\%MWCNT, (3) Ch/PLLA-2\%MWCNT, (4) Ch/PLLA-5\%MWCNT and (5) Ch/PLLA-10\% composites.

Table 1. Distribution of pore size. Average pore size $(\mu \mathrm{m})$ and porosity distribution (\%) of the chitosan/ PLLA, chitosan/PLLA-1\%MWCNT, chitosan/PLLA-2\%MWCNT, chitosan/PLLA-5\%MWCNT, and chitosan/PLLA-10\%MWCNT.

\begin{tabular}{ccccccc}
\hline Composite & $\begin{array}{c}\text { Average pore size } \\
(\mu \mathrm{m})\end{array}$ & $\begin{array}{c}<2 \mu \mathrm{m} \\
(\%)\end{array}$ & $\begin{array}{c}20-40 \mu \mathrm{m} \\
(\%)\end{array}$ & $\begin{array}{c}40-100 \mu \mathrm{m} \\
(\%)\end{array}$ & $\begin{array}{c}100-350 \mu \mathrm{m} \\
(\%)\end{array}$ & $\begin{array}{c}>350 \mu \mathrm{m} \\
(\%)\end{array}$ \\
\hline Chitosan/ PLLA & $96.48 \pm 78.23$ & 10.52 & 9.65 & 48.18 & 30.40 & 1.25 \\
Chitosan/PLLA-1\%MWCNT & $90.68 \pm 67.65$ & 2.05 & 12.85 & 54.00 & 30.35 & 0.74 \\
Chitosan/PLLA-2\%MWCNT & $83.31 \pm 86.51$ & 25.88 & 20.21 & 20.21 & 32.97 & 0.70 \\
Chitosan/PLLA-5\%MWCNT & $92.61 \pm 84.44$ & 13.68 & 5.47 & 51.24 & 28.1 & 1.49 \\
Chitosan/PLLA-10\%MWCNT & $51.58 \pm 34.30$ & 21.05 & 16.54 & 53.38 & 9.02 & 0 \\
\hline
\end{tabular}

\subsection{Cell Proliferation}

Cell proliferation of the composites after in vitro culture for 14 days was evaluated by Alamar Blue analysis. Figure 3 shows that the proliferation at 3 days of cell culture that Ch/PLLA-5\% MWCNT and Ch/PLLA-10\% MWCNT composites had a significantly higher number of cells, maintaining this tendency to day 7; at 14 days of the assay, showed a significant decrease in the rate of proliferation in Ch/PLLA-10\%MWCNT and Ch/PLLA$5 \%$ MWCNT. This is coincident when the osteoblast differentiation ends and becomes osteocyte, which is unable to continue proliferating [23]. Ch/PLLA-5\%MWCNT and Ch/PLLA-10\%MWCNT composites facilitated the adhesion and cell proliferation, and mineralized nodule formation, suggesting that these scaffolds have stimulant effects to promote proliferation rate and cell calcification, due to the surface roughness and porosity of the scaffold [24] [25]. Previous studies have reported that polymer matrices reinforced with concentrations greater than $2 \%$ by weight of MWCNT have a negative influence on cell growth, suggesting a maximum amount of MWCNT in which the surface roughness affects cell growth [26]. With the above results it is concluded that up to $10 \mathrm{wt} \%$ can be the maximum concentration of MWCNT, without negative implications on osteoblasts.

\subsection{Alkaline Phosphatase Activity}

In the other hand, osteoblasts reached an aging step, since the ALP activity was increased in the early stages of cell culture and at the end of the assay decreased, by the onset of calcification (Figure 4). Comparing Ch/PLLA and Ch/PLLA-MWCNT, greater activity was significantly observed at day 3 and 14 of cell culture of Ch/PLLA2\% MWCNT, Ch/PLLA-5\%MWCNT and Ch/PLLA-10\%MWCNT. These results suggest that the ALP activity of the cells increases proportionally with the percentage of MWCNT composites, this being indicative of osteoblast differentiation [25] [26].

\subsection{SEM Analysis and Mineralization}

Figure 5 shows the images on the 14 days of culture, observing the similar structure before culture once hy- 


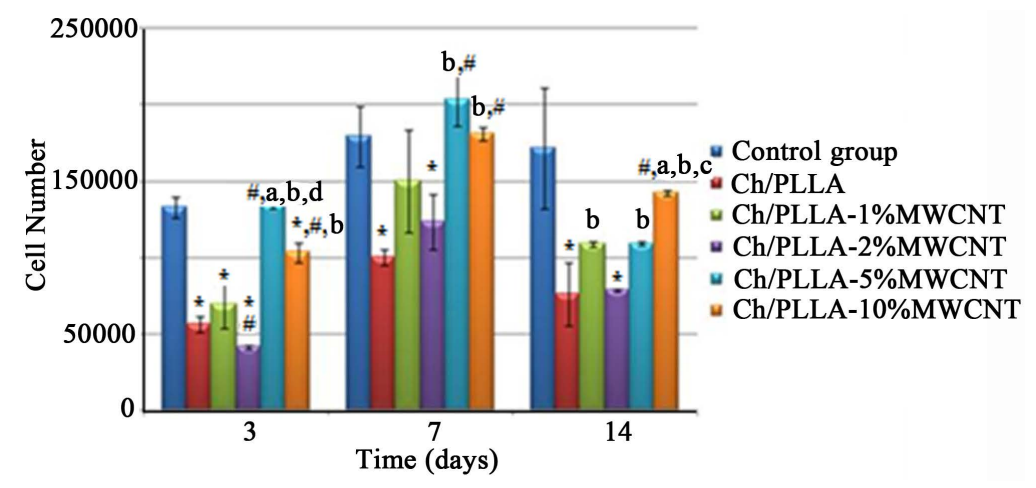
Figure 3 . Cell proliferation at 3,7 and 14 days of cell culture: ${ }^{*} p<0.05$ vs. control group ${ }^{\#} p$
$<0.05$ vs. Ch/PLLA a $p<0.05$ vs. Ch/PLLA-1\%MWCTN $\mathbf{b} p<0.05$ vs. Ch/PLLA-2\%
MWCTN $\mathbf{c} p<0.05$ vs. Ch/PLLA-5\%MWCTN $\mathbf{d} p<0.05$ vs. Ch/PLLA-10\%MWCTN.

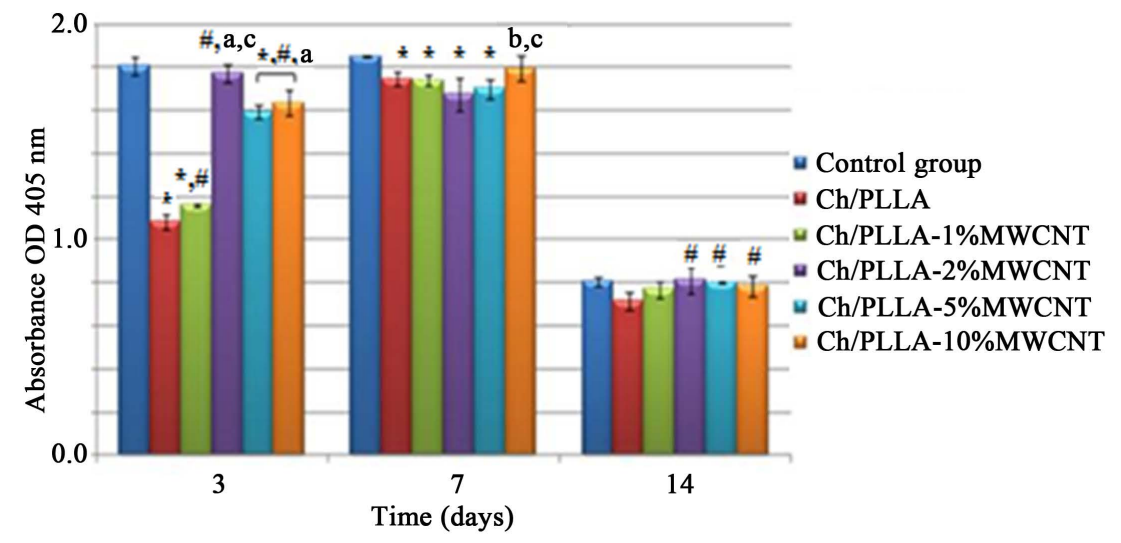

Figure 4. Alkaline phosphatase activity. ${ }^{*} p<0.05$ vs. Control group ${ }^{\#} p<0.05$ vs. Ch/PLLA a $p<0.05$ vs. Ch/PLLA-1\% MWCTN $\mathbf{b} p<0.05$ vs. Ch/PLLA-2\%MWCTN $\boldsymbol{c} p<0.05$ vs. Ch/PLLA-5\%MWCTN d $p<0.05$ vs. Ch/PLLA-10\%MWCTN.

drated with cell culture medium. The images reveal the presence of adherent cells on the substrate and spread uniformly, with a greater number of cells in Ch/PLLA-2\%MWCNT,Ch/PLLA-5\%MWCNT and Ch/PLLA-10\% MWCNT (Figure 5(d), Figure 5(g), Figure 5(j)), and evidence of a migration between the pores of the composite. MWCNT nanometer size is close to filopodium osteoblastic, therefore, the distal end of filopodium interacts with MWCNT, giving a high capacity of adherence [21]. At higher magnification (Figure 5(d), Figure 5(e), Figure 5(h), and Figure 5(k)), the preserved morphology of osteoblasts can be observed, tending to extend small filopoidales projections indicative of cell adhesion to the composite. In Figure 5(c), Figure 5(f), Figure 5(i), and Figure 5(I) can be observed incipient formation of HAp crystals, hexagonal morphology as reported in the literature [27], in Ch/PLLA-2\% MWCNT (Figure 5(f)), Ch/PLLA-5\%MWCNT (Figure 5(i)) and Ch/PLLAz10\%MWCNT (Figure 5(I)). The image shows that the scaffold containing MWCNT have a positive influence on osteoblasts, promoting cell adhesion and spreading. Figure 6 and Figure 7 correspond to the FT-IR analysis of composites at 14 days of cell culture, showing absorption bands corresponding to $\mathrm{PO}_{4}\left(1089 \mathrm{~cm}^{-1}, 960 \mathrm{~cm}^{-1}\right)$ and $\mathrm{CO}_{3}\left(1458 \mathrm{~cm}^{-1}\right.$ and $\left.1462 \mathrm{~cm}^{-1}\right)$, [28] [29].

Figure 8 shows the diffraction pattern of the composite Ch/PLLA/MWCNT in different percentages on the 14 day of cell culture. The shift of the peaks corresponding to HAp were $22^{\circ}, 26^{\circ}, 40^{\circ}, 45^{\circ}$ and $50^{\circ}$, in the scale of $2 \theta$, the broadening of the RX diffraction peaks indicates the small size of the crystals of HAp formed in situ [30]. XRD patterns show the presence of HAp, these results are consistent with the images obtained by SEM.

\section{Conclusion}

Within the reinforced composite, proliferation of osteoblast cells was demonstrated and significantly higher ALP content with the addition of 5\% and 10\%-MWCNT, further facilitating adhesion and mineralized nodule 

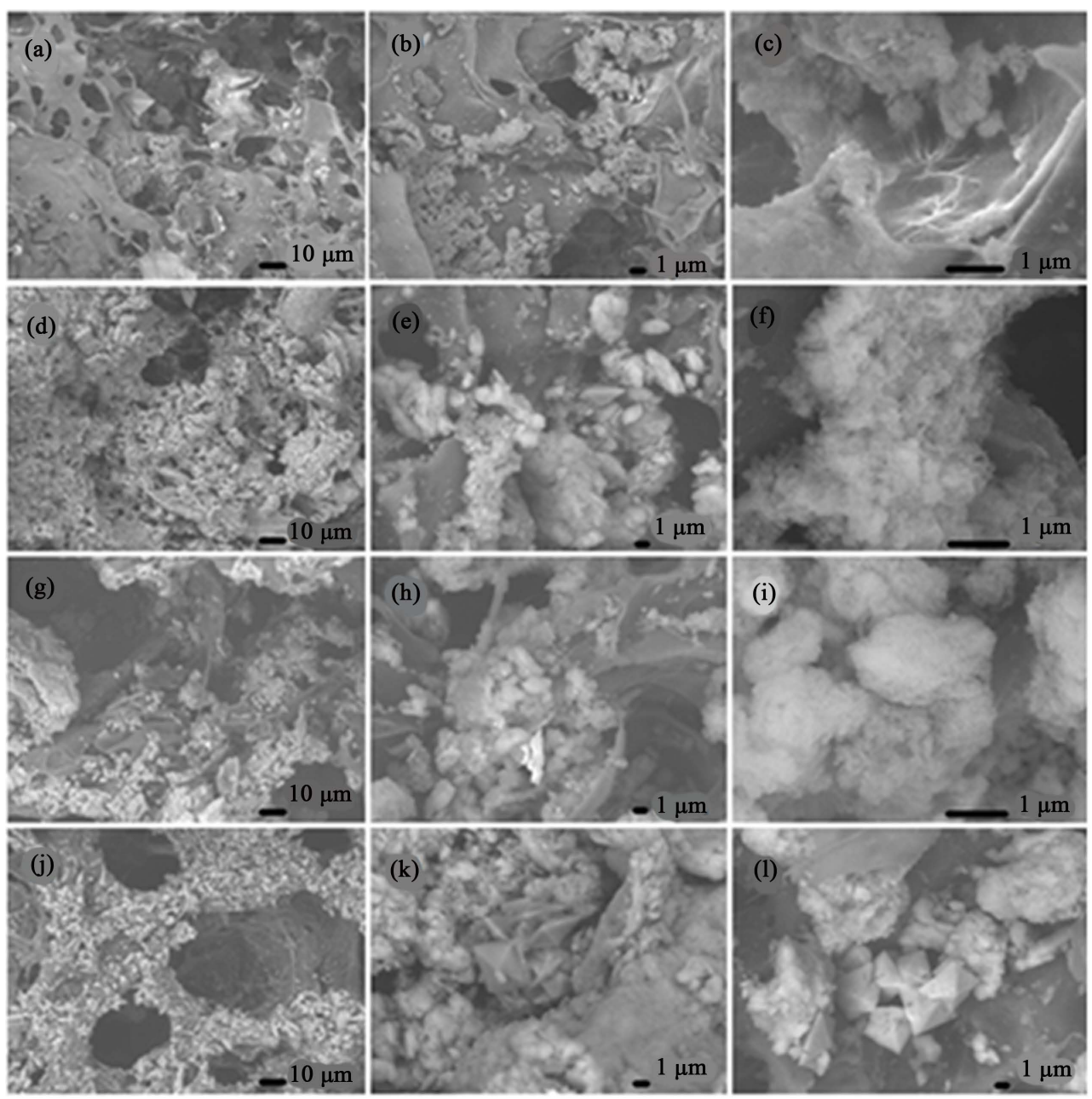

Figure 5. Scanning electron micrographs of cell-seeded on composite after 14 days of culture. (a), (b), and (c) Ch/PLLA-1\%MWCNT; (d), (e), and (f) Ch/PLLA-2\%MWCNT; (g), (h), and (i) Ch/ PLLA-5\%MWCNT; (j), (k), and (l) Ch/PLLA-10\% MWCNT.

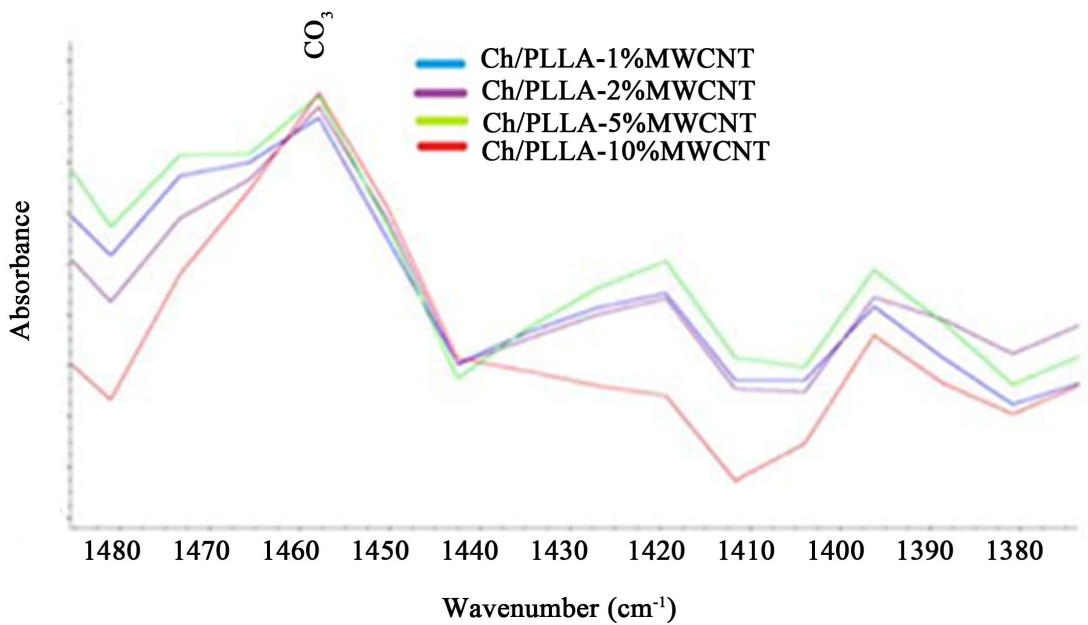

Figure 6. FTIR spectra of the Ch/PLLA, Ch/PLLA-1\%MWCNT, Ch/PLLA-2\%MWCNT, Ch/ PLLA-5\%MWCNT and Ch/PLLA-10\% composites seeded with osteoblasts at day 14 . The spectra observed the characteristic peaks of calcium carbonate $\left(1462 \mathrm{~cm}^{-1}, 1458 \mathrm{~cm}^{-1}\right)$. 


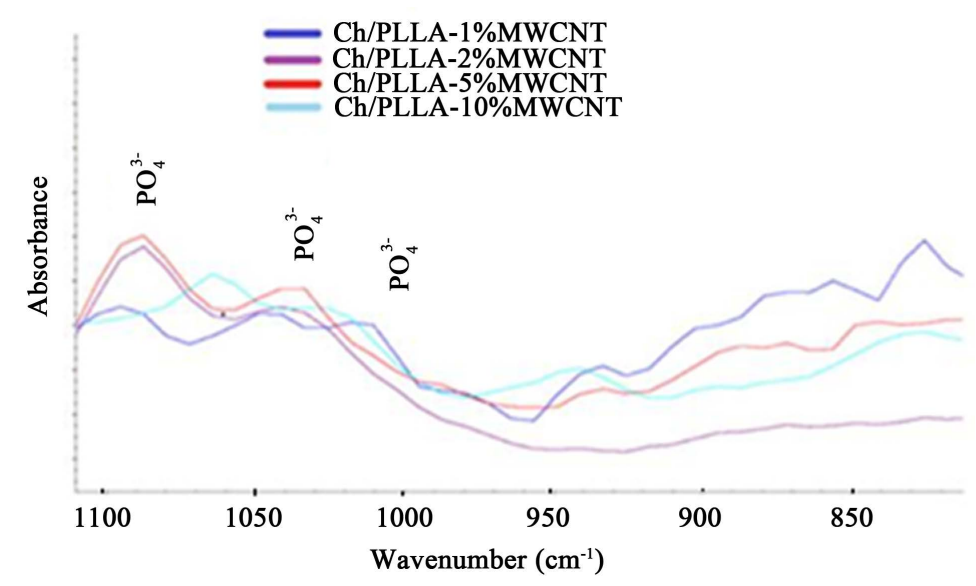

Figure 7. FTIR spectra of the Ch/PLLA, Ch/PLLA-1\%MWCNT, Ch/PLLA-2\%MWCNT, Ch/PLLA-5\%MWCNT and Ch/PLLA-10\% composites seeded with osteoblasts at day 14. The spectra observed the characteristic peaks of calcium phosphate $\left(1089 \mathrm{~cm}^{-1}\right.$ y $\left.960 \mathrm{~cm}^{-1}\right)$.

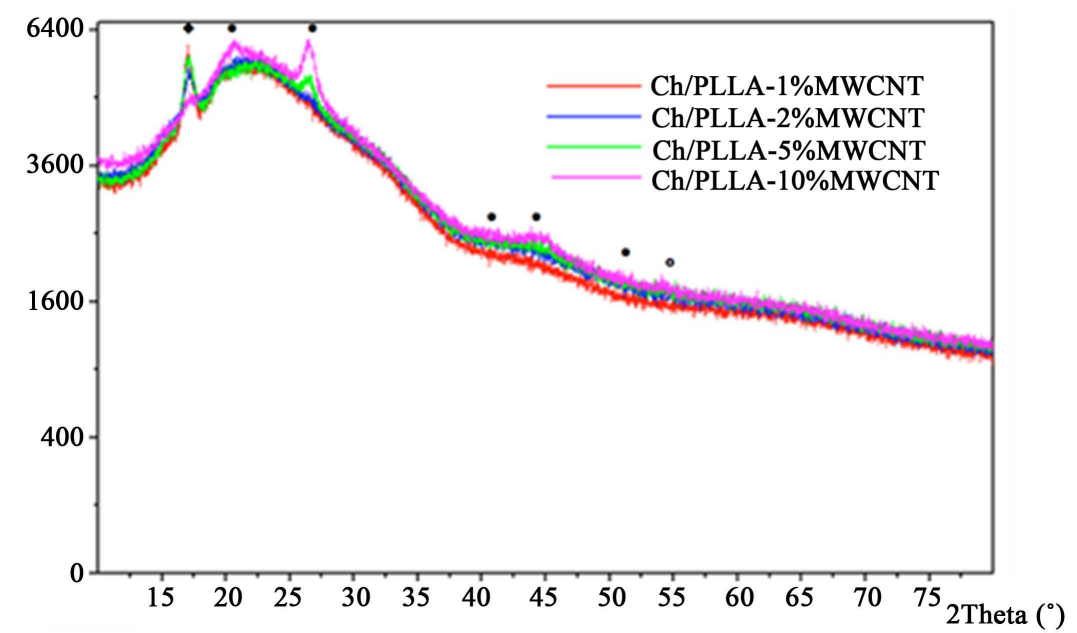

Figure 8. X-ray diffraction of the composites Ch/PLLA with different percentages of MWCNT at 14 days of culture. The characteristic peaks of HAp (•), MWCNT ( ${ }^{\circ}$ ), and chitosan $(\bullet)$ are observed.

formation. Osteoblasts cultured in the composite could migrate to the depth of pores, forming crystals of HAp on the composite surface. The fabrication and characterization of composites reinforced with MWCNT, still represented a challenge for materials engineering, since, CNT was a promising material for developing the next generation of scaffolds in tissue engineering.

\section{Acknowledgements}

The financial support of the Mexican Public Education Secretary (PROMEP) and the Mexican National Council for science and Technology and Chihuahua state Government (FOMIX) through project PROMEP 103.5/10/ 4995 and CHIH-2010-C01-148041.

\section{References}

[1] Fernández-Tresguerres, Hernández-Gil, I., Alobera Gracia, M.A., del Canto Pingarón, M. and Blanco Jerez, L. (2006) Bases fisiológicas de la regeneración ósea II. El proceso de remodelado. Medicina Oral Patolología Oral y Cirugía Bucal, 11, 151-157.

[2] Chahal, S., Jahir, F., Kumar, A., Bahair, M. and Mohd, M. (2016) Fabrication, Characterization and in Vitro Biocom- 
patibility of Electrospun Hydroxyethyl Cellulose/Poly (Vinyl) Alcohol Nanofibrous Composite Biomaterial for Bone Tissue Engineering. Chemical Engineering Science, 144, 17-29. http://dx.doi.org/10.1016/j.ces.2015.12.030

[3] Yilgor, P., Sousa, R.A., Reis, R.L., Hasirci, N. and Hasirci, V. (2010) Effect of Scaffold Architecture and BMP-2/ BMP-7 Delivery on in Vitro Bone Regeneration. Journal of Materials Science: Materials in Medicine, 21, 2999-3008. http://dx.doi.org/10.1007/s10856-010-4150-1

[4] Martel-Estrada, S.A., Martínez-Pérez, C.A., Chacón-Nava, J.G., García-Casillas, P.E. and Olivas-Armendáriz, I. (2010) In Vitro Bioactivity of Chitosan/Poly (D,L-Lactide-co-Glycolide) Composites. Materials Letters, 65, 137-141. http://dx.doi.org/10.1016/j.matlet.2010.09.022

[5] Olivas-Armendáriz, I., García-Casillas, P., Martel-Estrada, A., Martinez-Sánchez, R., Martínez-Villafañe, A. and Martínez-Pérez, C.A. (2009) Preparación y caracterización de compositos de quitosana/nanotubos de carbono. Revista Mexicana de Ingeniería Química, 8, 205-211.

[6] Kim, I.Y., Seo, S.J., Moon, H.S., Yoo, M.K., Park, I.Y., Kim, B.C. and Cho, C.S. (2008) Chitosan and Its Derivatives for Tissue Engineering Applications. Biotechnology Advances, 26, 1-21. http://dx.doi.org/10.1016/j.biotechadv.2007.07.009

[7] Sangkert, S., Kamonmattayakul, S., Lin, W. and Meesane, J. (2016) A Biofunctional-Modified Silk Fibroin Scaffold with Mimic Reconstructed Extracellular Matrix of Decellularized Pulp/Collagen/Fibronectin for Bone Tissue Engineering in Alveolar Bone Resorption. Materials Letters, 166, 30-34. http://dx.doi.org/10.1016/j.matlet.2015.12.032

[8] Vachirajov, N., Ratanavaraporn, J., Damrongsakkul, S., Pichyangkura, R., Banaprasert, T. and Kanokpanont, S.A. (2009) Comparison of Thai Silk Fibroin-Based and Chitosan-Based Materials on in Vitro Biocompatibility for Bone Substitutes. International Journal of Biological Macromolecules, 45, 470-477. http://dx.doi.org/10.1016/j.ijbiomac.2009.07.010

[9] Manjubala, I., Ponomarev, I., Wilke, I. and Jandt, K.D. (2007) Growth of Osteoblast-Like Cells on Biomimetic Apatite-Coated Chitosan Scaffolds. Journal Biomedical Materials Research Part B, Applied Biomaterials, 84, 7-16.

[10] Armentano, I., Dottori, M., Fortunati, E., Matioli, S. and Kenny, J.M. (2010) Byodegradable Polymer Matrix Nanocomposites for Tissue Engineering: A Review. Polymer Degradation and Stability, 95, 2126-2146. http://dx.doi.org/10.1016/j.polymdegradstab.2010.06.007

[11] Sahithi, K., Swetha, M., Ramasamy, K., Srinivasan, N. and Selvamurugan, N. (2010) Polymeric Composites Containing Carbon Nanotubes for Bone Tissue Engineering. International Journal of Biological Macromolecules, 46, 281-283. http://dx.doi.org/10.1016/j.ijbiomac.2010.01.006

[12] Gopalan, A.I., Lee, K.P., Santhosh, P., Kim, K.S. and Nho, Y.C. (2006) Different Types of Molecular Interactions in Carbon Nanotube/Conducting Polymer Composites-A Close Analysis. Composites Science and Technology, 67, 900905. http://dx.doi.org/10.1016/j.compscitech.2006.02.036

[13] Feng, X., Liao, G., He, W., Sun, Q., Jian, X. and Du, J. (2009) Preparation and Characterization of Functionalized Carbon Nanotubes/Poly(phthalazinone ether sulfone ketone)s Composites. Polymer Composites, 30, 365-373. http://dx.doi.org/10.1002/pc.20561

[14] Bokobza, L. (2008) Multiwall Carbon Nanotube Elastomeric Composites: A Review. Polymer, 48, 4907-4920. http://dx.doi.org/10.1016/j.polymer.2007.06.046

[15] Lobo, A.O., Corat, M.A.F., Antunes, E.F., Palma, M.B.S., Pacheco-Soares, C., García, E.E. and Corat, E.J. (2010) An Evaluation of Cell Proliferation and Adhesión on Vertically Aligned Multi-Walled Carbón Nanotube Films. Carbon, 48, 245-254. http://dx.doi.org/10.1016/j.carbon.2009.09.012

[16] Bacakova, L., Filova, E., Parizek, M., Ruml, T. and Svorcik, V. (2011) Modulation of Cell Adhesion, Proliferation and Differentiation on Materials Designed for Body Implants. Biotechnology Advances, 29, 739-767. http://dx.doi.org/10.1016/j.biotechadv.2011.06.004

[17] Murphy, C.M., Haugh, M.G. and O’Brien, F.J. (2010) The Effect of Mean Pore Size on Cell Attachment, Proliferation and Migration in Collagen-Glycosaminoglycan Scaffolds for Bone Tissue Engineering. Biomaterials, 31, 461-466. http://dx.doi.org/10.1016/j.biomaterials.2009.09.063

[18] Misra, S.K., Ohashi, F., Valappil, S.P., Knowles, J.C., Roy, I., Ravi, S., Silva, P., Salih, V. and Boccaccini, A.R. (2010) (Characterization of Carbon Nanotube (MWCNT) Containing P(3HB)/Bioactive Glass Composites for Tissue Engineering Applications. Acta Biomaterialia, 6, 735-742. http://dx.doi.org/10.1016/j.actbio.2009.09.023

[19] Kalmodia, S., Goenka, S., Laha, T., Lahiri, D., Basu, B. and Balani, K. (2010) Microstructure, Mechanical Properties, and in Vitro Biocompatibility of Spark Plasma Sintered Hydroxyapatite-Aluminum Oxide-Carbon Nanotube Composite. Materials Science and Engineering: C, 30, 1162-1169. http://dx.doi.org/10.1016/j.msec.2010.06.009

[20] Bocaccini, A.R., Chicatun, F., Cho, J., Bretcanu, O., Roether, J.A., Novak, S. and Chen, Q.Z. (2007) Carbon Nanotube Coatings on Bioglass-Based Tissue Engineering Scaffolds. Advanced Functional Materials, 17, 2815-2822. http://dx.doi.org/10.1002/adfm.200600887 
[21] Collins, M.T. and Boehm, M. (2011) It ANKH Necessarily So. The Journal of Clinical Endocrinology Metabolism, 96, 72-74. http://dx.doi.org/10.1210/jc.2010-2614

[22] Lin, C., Wang, Y., Lai, Y., Yang, W., Jiao, F., Zhang, H., Ye, Z. and Zhang, Q. (2011) Incorporation of Carboxylation Multiwalled Carbon Nanotubes into Biodegradable Poly(lacti-co-glycolic acid) for Bone Tissue Engineering. Colloids and Surfaces B, 83, 367-375. http://dx.doi.org/10.1016/j.colsurfb.2010.12.011

[23] Watari, F., Akasaka, T., Li, X., Uo, M. and Yokoyama, A. (2009) Proliferation of Osteoblasts Cells on Nanotubes. Frontier of Materials Science in China, 3, 169-173. http://dx.doi.org/10.1007/s11706-009-0034-z

[24] Elias, K.L., Price, R.L. and Webster, T.J. (2002) Enhanced Functions of Osteoblasts on Nanometer Diameter Carbon Fibers. Biomaterials, 23, 3279-3287. http://dx.doi.org/10.1016/S0142-9612(02)00087-X

[25] Aoki, N., Akasaka, T., Watari, F. and Yokoyama, A. (2007) Carbon Nanotubes as Scaffolds for Cell Culture and Effect on Celular Functions. Dental Materials Journal, 26, 178-185. http://dx.doi.org/10.4012/dmj.26.178

[26] Okada, S., Ito, H., Nagai, A., Komotori, J. and Imai, H. (2010) Adhesion of Osteoblast-Like Cells on Nanostructured Hydroxyapatite. Acta Biomaterialia, 6, 591-597. http://dx.doi.org/10.1016/j.actbio.2009.07.037

[27] Martel-Estrada, S.A., Olivas-Armendáriz, I., Martínez-Pérez, C.A., Hernàndez, T., Acosta-Gómez, E.I., Chacón-Nava, J.G., Jiménez-Vega, F. and García-Casillas, P.E. (2012) Chitosan/Poly(DL, lactide-co-glycolide) Scaffolds for Tissue Engineering. Journal of Materials Science: Materials in Medicine, 23, 2893-2901. http://dx.doi.org/10.1007/s10856-012-4762-8

[28] Zhang, F., Weidmann, A., Nebe, J.B. and Burkel, E. (2010) Osteoblast Cell Response to Surface-Modified Carbon Nanotubes. Materials Science and Engineering: C, 32, 1057-1061. http://dx.doi.org/10.1016/j.msec.2010.07.007

[29] Xu, J.L., Khor, K.A., Sui, J.J. and Chen, W.N. (2009) Preparation and Characterization of a Novel Hydroxyapatite/Carbon Nanotubes Composite and Its Interaction with Osteoblast-Like Cells. Materials Science and Engineering: C, 29, 44-49. http://dx.doi.org/10.1016/j.msec.2008.05.009

[30] Firme, C.P. and Bandaru, P.R. (2010) Toxicity Issues in the Application of Carbon Nanotubes to Biological Systems. Nanomedicine, 6, 245-256. http://dx.doi.org/10.1016/j.nano.2009.07.003 